\title{
THE INTERNATIONAL HUMAN RIGHT TO HOUSING \& THE CANADIAN CHARTER: A CASE COMMENT ON TANUDJAJA V CANADA (ATTORNEY GENERAL)
}

\author{
David DesBaillets*
}

The case of Tanudjaja $\mathrm{v}$ Attorney General, represents an unprecedented opportunity for Canadian legal scholars to examine the right to adequate housing in the Canadian human rights context. It is the only legal challenge that broaches directly the right to housing under Canadian law, basing its arguments on two key elements contained in the Charter of Rights and Freedoms: sections 7 and 15. Moreover, the case represents an attempt by the claimants to bolster their Charter claim with reference to housing rights found in international human rights law. For Canadian housing rights' scholars, this decision, though ultimately quite negative in its conclusions, demonstrates the need for a better understanding of the intersection between international legal norms on human rights on the one hand, and the Charter, on the other. It does not, however, adequately portray the full extent of the former's influence on the latter, as Justice Lederer of the Ontario Superior Court of Justice failed to address the importance of international legal doctrine with respect to the interpretation of positive social and human rights in the Canadian legal context. In particular, he ignored the growing body of Charter related cases and precedents in Canadian jurisprudence that shed light on the complex relationship between fundamental human rights enshrined in various international legal documents and the recognized positive obligations they impose on the government of Canada to implement them under such long established treaties as the Covenant of Economic Social and Cultural Rights.

In this comment, the author makes a critique of the analysis undertaken by Justice Lederer with regard to the relevance of international human rights norms in the context of Tanudjaja, by comparing it with past Charter jurisprudence involving the impact of these on Canadian human rights claims.

L'affaire Tanudjaja c Attorney General est une occasion unique pour les spécialistes en droit du Canada d'examiner le droit à un logement adéquat dans le contexte des droits de la personne protégés au Canada. Il s'agit du seul litige dans lequel le droit au logement en droit canadien est abordé directement sous l'angle de deux dispositions clés de la Charte canadienne des droits et libertés: les articles 7 et 15. De plus, dans cette même affaire, les demandeurs ont tenté d'étoffer leur allégation fondée sur la Charte en invoquant les droits au logement reconnus dans le droit international sur les droits de la personne. Pour les spécialistes en matière de droits au logement au Canada, malgré les conclusions plutôt négatives qui y sont tirées, cette décision illustre la nécessité de mieux comprendre l'interaction entre les normes juridiques internationales sur les droits de la personne, d'une part, et la Charte, d'autre part. Cependant, elle ne décrit pas adéquatement l'ampleur de l'influence des premières sur la seconde, puisque le juge Lederer, de la Cour supérieure de justice de l'Ontario, n'a pas abordé l'importance 
de la doctrine juridique internationale relative à l'interprétation des droits sociaux et humains positifs dans le contexte juridique canadien. Plus précisément, il a ignoré le nombre croissant de décisions canadiennes liées à la Charte qui ont mis en lumière la relation complexe entre les droits humains fondamentaux garantis dans différents documents juridiques internationaux et les obligations positives reconnues que ces textes imposent au gouvernement du Canada en ce qui a trait à la mise en ouvre de ces droits en conformité avec des traités d'aussi longue date que le Pacte international relatif aux droits économiques, sociaux et culturels.

Dans ce commentaire, l'auteur critique l'analyse que le juge Lederer a menée au sujet de la pertinence des normes internationales à l'égard des droits de la personne dans le contexte de l'affaire Tanudjaja, en comparant cette analyse à des décisions antérieures concernant la Charte et faisant état des répercussions de ces normes sur les revendications fondées sur les droits de la personne au Canada.

\section{INTRODUCTION}

In the case of Tanudaja $v$ Canada (Attorney General), the presiding justice, Lederer J., had to contend with several different issues relating to the claim of the applicants (Ms. Tanudjaja, et al.). ${ }^{1}$ The latter's claim was based, primarily, on section 7 and 15 of the Charter, but also contained a significant element of international human rights law with respect to the right to adequate housing. It is this last point that will serve as the focus of this case comment.

Although international human rights and international public law have been regarded as important guidelines for judges in Canada, especially since the coming into force of the Charter of Rights and Freedoms, (itself, largely inspired by international legal norms) the connection between Canadian human rights and international human rights law, has always been rather awkward for the Canadian judiciary. Judges have traditionally been reluctant to apply international human rights norms, in the domestic context, often invoking the non-justiciability of such rights where there is no corresponding internal piece of legislation which implements them, even where the international legal instrument in question, has been signed and ratified by the Canadian government. Sometimes, this reluctance was hidden behind the technically correct but somewhat tired argument that, by virtue of the dualist nature of Canada's legal system, any enforcement of human rights norms found at the international level, that have not been fully integrated in the domestic legal framework, would be a breach of parliamentary sovereignty and the

\footnotetext{
The author is a $5^{\text {th }}$ year doctoral candidate and teacher of law at the University of Quebec in Montreal. This paper evolved out of research for his doctoral thesis and constitutes an important element of his dissertation. He would like to thank the Canadian Association of Law and Society for inviting him to present this work at their conferences. He is also grateful to his supervisor Hugo Cyr, Professor Martha Jackman at the University of Ottawa for her encouragement and his colleague and friend Will Colish for his timely editing work. Last but not least, the team at the Windsor Yearbook on Access to Justice for publishing his first journal article.

$1 \quad$ Tanudjaja v Attorney General (Canada) (Application), 2013 ONSC 5410.
} 
fundamental separation of powers principle that divides the judiciary, executive and legislative branches of government. $^{2}$

In this instance, the analysis by Lederer J., of the Ontario Superior Court, of the laws surrounding the right to adequate housing in Canada, barely mentions international human rights norms on the subject, despite agreeing to allow Amnesty International Canada and others to intervene on behalf of the claimants, as parties to the litigation. ${ }^{3}$ His almost total dismissal of the relevance of such well-respected and fundamental human rights documents as the Universal Declaration of Human Rights ${ }^{4}$ or the International Covenant on Economic, Social and Cultural Rights [ICESCR], which contains a right to adequate housing in article $11,{ }^{5}$ is not only divergent with the evidence presented by these parties, but is also inconsistent with the existing Charter jurisprudence which deals with the intersection between Canadian and international human rights law. Finally, the decision does not take into account the Canadian government's position with respect to the importance of these international legal documents in the Canadian legal context.

In this comment, I will first give readers the background of the Tanudjaja case. I will then describe Justice Lederer's analysis, found primarily in his response to the applications for intervenor status and the motion to dismiss the application filed by the Attorneys General of Canada and Ontario, of the relevant international human rights norms with respect to section 7 and 15 of the Charter. As well, this section includes a brief examination of the setback encountered by Ms. Tanudjaja at the Ontario Court of Appeal and the Supreme Court of Canada.

In section II, I will begin my critical assessment of Justice Lederer's views on the impact of international legal norms in the application of human rights in the Canadian legal context. In doing so, I intend to illustrate some of the key decisions with respect to the intersection between Charter claims and international human rights norms, as defined by courts in Canada, and will focus primarily on the jurisprudence of the Supreme Court of Canada.

In section III, I will go into greater detail on the question of the relationship between certain sections of the Charter and the international legal human rights doctrines which have been applied to them in the case law of the Supreme Court. Specifically, I will examine the extent to which Section 7 has been interpreted by judges in the light of some important developments that have occurred at the international level, with respect to the meaning of that section's "right to life, liberty and the security of the person," as well as the qualifying clause "...the right not to be deprived thereof except in accordance with the

2 In paragraph 60 of the Suresh judgement the Court unanimously held that "International treaty norms are not, strictly speaking, binding in Canada unless they have been incorporated in Canadian law by enactment." Suresh v Canada (Minister of Citizenship and Immigration), 2002 SCC 1, [2002] 1 SCR 3.

3 Tanudjaja, supra note 1 at para 52.

4 Universal Declaration of Human Rights (UDHR) (1948) UNGA Res 217 A (II) (adopted 10 December 1948).

5 Article 11 of the ICESCR states "The States Parties to the present Covenant recognize the right of everyone to an adequate standard of living for himself and his family, including adequate food, clothing and housing (emphasis added), and to the continuous improvement of living conditions. The States Parties will take appropriate steps to ensure the realization of this right, recognizing to this effect the essential importance of international co-operation based on free consent." International Covenant on Economic, Social and Cultural Rights, 3 January 1976, available online at the United Nations Human Rights: Office of the High Commissioner for Human Rights:

$<$ http://www.ohchr.org/EN/ProfessionalInterest/Pages/CESCR.aspx>. 
principles of fundamental justice". ${ }^{6}$ The larger purpose of this section is to contrast their analyses with that of Lederer's judgement in Tanudjaja. Finally, I will conduct a comparative analysis of the Supreme Court jurisprudence in the field of equality rights (section 15) which has similarly employed international human rights norms in their arguments with those adopted by Lederer in his ruling to quash the application of Ms. Tanudjaja.

These arguments will serve to illustrate the essential purpose of this comment: namely, that Lederer J.'s reasoning in Tanudjaja, failed to take into account the significant influence of established international human rights norms, such as the right to adequate housing, on related Canadian human rights enumerated in the Charter of Rights and Freedoms, specifically s.15 and s.7.

The principal aim of this exercise is to supply further material for the discussion surrounding the right to housing in Canada, engendered by this case. Tanudjaja raises a number of points of law that remain difficult to answer for the Canadian human rights scholar. In particular, why are the courts so reluctant to invoke international human rights norms, especially those involving social rights, with respect to human rights claims domestically? What does Canadian case law have to say on the matter? Finally, why have the courts largely failed to incorporate the position of Canada's own government with respect to the relevance of established international human rights norms, in their decisions?

\section{TANUDJAJA V. ATTORNEY GENERAL (CANADA)}

\section{A. Background}

The Tanudaja v. Attorney General (Canada) ${ }^{7}$ case is a collective legal action involving the claimant (Ms. Tanudjaja) and a group of co-applicants who, with the help of various social-justice oriented civil society organizations (most notably the Canadian Centre for Rights and Equality in Accommodation or CERA) filed suit in May of 2010. ${ }^{8}$ Ms. Tanudjaja, and her fellow claimants allege that the Federal government and the government of Ontario had violated their human rights (section 15 and 7) under the Charter of rights and freedoms by "creating and maintaining the conditions that create and lead to the sustaining of homelessness and inadequate housing." Moreover, their application to the Ontario Superior Court requested that it impose an order on the Federal and Provincial governments to implement a strategy that would alleviate both homelessness and sub-standard living conditions in Canada. ${ }^{10}$ Despite the Courts ruling against Ms. Tanudaja and her co-applicants, the legal question they raised remains a valid one. ${ }^{11}$

6 See section 7 of the Canadian Charter of Rights and Freedoms, Part 1 of the Constitution Act, 1982, being Schedule B to the Canada Act 1982 (UK), 1982, c 11.

7 Tanudjaja, supra note 1.

8 For a detailed account of the applicants' team see Fay Faraday, et al., "Fighting for the Right to Housing" (2015) 24:2 J Law \& Soc Pol'y 10.

9 Laurie Monsebraaten, "Toronto homeless launch Charter challenge", The Toronto Star (27 May 2010) online: Toronto Star < http://www.thestar.com/news/gta/2010/05/27/toronto_homeless_launch_charter_challenge.html .

10 Ibid.

11 Chris Schmitz, "Homeless Advocates Push for One Final Hearing at Top Court: Tension in Court of Appeal Decision Between Role of Courts and State in Socio-Economic Issues", The Lawyers Weekly (19 December 2014) online: The Lawyers Weekly $<$ http://www.lawyersweekly.ca/index.php?section=article\&volume=34\&number=31\&article $=1>$. 
The case is unique in Canadian jurisprudence in that it represents the first time that a claimant has based a legal action, in part, on the right to adequate housing under international law. Thus, it is worth examining the reasoning behind Justice Lederer's decision to grant the motion to dismiss, in order to discern the chances for a successful appeal in the future.

\section{B. Lederer J.'s Analysis of the Relationship Between the International Law of the Right to Adequate Housing and Charter rights $7 \& 15$ in the Preliminary Phase of the Application.}

It transpired that Justice Lederer heard from a number of parties that applied for intervenor status in the case. Each of these civil society organizations filed facta on behalf of the applicants. Though all of them were arguing in favour of recognition of the right to adequate housing in Canadian law, only a handful spoke to the importance of international human rights norms with regard to deciding the case. These were Amnesty International Canada, and the International Network of Economic, Social and Cultural rights [ESCR-Net].

In their submission to the Court, which was designed to defeat the Respondent's (Attorney General of Canada's) motion to dismiss their contribution to the case, Amnesty partnered with ESCR-Net, petitioning the judge for their inclusion, on the grounds that "the Court will be required to consider how Canada's international human rights obligations inform domestic rights under the Charter." ${ }^{\prime 2}$

Furthermore, in the sections dealing with the arguments being raised by Amnesty and ESCR-Net for consideration by the courts, the organizations made the point that they both had "an interest in the relationship between Canada's international human rights obligations and the Charter rights of life, liberty, security of the person and freedom from discrimination."13

CERA also submitted arguments to the effect that international legal conventions, in particular the International Convention on Economic, Social and Cultural Rights must be interpreted as imposing binding positive obligations on the Canadian government, including providing access to adequate housing to those who have none. ${ }^{14}$ Furthermore, they made the case that government policies and legislation on housing at both levels have led to a greater decline in the quality and quantity of affordable, accessible and adequate housing in Canada, and that this situation potentially breaches the country's obligations under the Covenant, to provide a legal environment that respects, protects and fulfills, in the language of the ICESCR, this vital human right. This claim is well supported by the scholarship in the area of international social and economic rights and has been noted by many international jurists. "A general decline in living and housing conditions directly attributable to policy and legislative decisions by state parties and in the absence of accompanying compensatory measures would be inconsistent with the obligations under the Covenant." 15

In his response to their submission, Lederer J. was initially sympathetic to the arguments put forward by Amnesty and others. Citing their expertise on the six international treaties in the Amended Notice of

12 Tanudjaja v Attorney General Canada, Attorney General Ontario, OSCJ CV-10-403688 Motion for Leave to Intervene, Factum of the Moving Party (Amnesty Canada/ESCR-NET COALITION), at para 2.

13 Ibid at para 32.

14 Tanudjaja v Attorney General of Canada, Attorney General of Ontario OSCJ CV-10-403688, Amended Notice of Application (CERA), at para 10.

15 Scott Leckie \& Anne Gallagher, Economic Social and Cultural Rights: A Legal Resource Guide (Philadelphia: University of Pennsylvania, 2006) at 295. 
Application and the need for the Court to understand these, he stated that "an understanding of the proper application of these treaties to Canadian law may provide additional insight into how s. 7 and s. 15 of the Charter could reasonably be interpreted such that it is not plain and obvious that the application cannot succeed"16 Therefore, Amnesty and ESCR-net, among others, were granted intervenor status in the case, but only if they respected certain conditions. They were required to limit their arguments to shedding light on how the relevant international instruments might assist in the interpretation of sections 7 and 15 of the Charter, as it relates to a right to adequate housing in the Canadian context. ${ }^{17}$

Amnesty's intervention in the application was accepted. Irrespective, the sympathy for their international human rights perspective, shown at this stage of the proceedings by the Judge, would not carry over to considerations with respect to the Tanudjaja application itself. As I will demonstrate, Lederer J. would barely acknowledge the influence of international legal sources on Canadian human rights jurisprudence in his final ruling.

\section{The Decision of the Ontario Court of Appeal in Tanudjaja v. Attorney General (Canada)}

On the 1st of December 2014, the Ontario Court of Appeal handed down its ruling in Ms. Tanudjaja's appeal. ${ }^{18}$ The results have little bearing on my analysis of the application from an international human rights perspective and, hence, do not require a detailed description here. Suffice it to say, though neither the majority opinion of Pardu J.A., nor the dissenting opinion Feldman J.A., address the relevance of international human rights norms in interpreting s.7 and 15 of the Charter, they did give the appellants some cause for optimism.

In the former's case (Pardu J.A.), the conclusion was that policy matters can be justiciable under special circumstances, and that, contrary to Lederer's judgment ${ }^{19}$, the objections that a question is too political or too complex for the courts, will not automatically succeed, especially in a Charter claim:

I add that complexity alone, sensitivity of political issues, the potential for significant ramifications flowing from a court decision and a preference that legislatures alone deal with a matter are not sufficient on their own to permit a court to decline to hear a matter on the ground of justiciability. ${ }^{20}$

The opinion of the dissenting judge was even more critical of Justice Lederer's assessment of the legal arguments, stating that his motion to dismiss the appeal under Rule 21 of the Rules of Civil Procedure, ${ }^{21}$ was premature and ill-advised, given the compelling nature of evidence put forward in support of Ms. Tanudjaja's claims and those of the coalition of groups, including Amnesty International Canada, that intervened on her behalf:

Tanudjaja, supra note 1 at para 45.

Ibid at para 52.2.

Tanudjaja v Canada (AG), 2014 ONCA 852 (available on CanLII) [Tanudjaja, Appeal].

19 See paragraph 143 where he states "the courts are not the proper place to determine the wisedom of policy choices involved in balancing concerns for the supply of appropriate housing against the myriad of other concerns associated with the broad policy review this Application envisages" Tanudjaja, supra note 1 .

20 Tanudjaja, Appeal, supra note 18 at para 35.

21 See Rules of Civil Procedure, RRO 1990, Reg 194 at ss 8, 21. 


\begin{abstract}
This application is simply not the type of "hopeless" claim for which Rule 21 was intended. It has been brought by counsel on behalf of a large, marginalized, vulnerable and disadvantaged group who face profound barriers to access to justice. It raises issues that are basic to their life and well-being. It is supported by a number of credible intervening institutions with considerable expertise in Charter jurisprudence and analysis. The appellants put together a significant record to support their application. That record should be put before the court. ${ }^{22}$
\end{abstract}

Thus, as far as the opinion of Feldman J.A. is concerned, the claim, as defined by Ms. Tanudjaja, remains potentially justiciable, and deserved its day in court.

\title{
III. ANALYSIS WITH RESPECT TO THE IMPACT OF INTERNATIONAL HUMAN RIGHTS NORMS ON THE CHARTER OF RIGHTS AND FREEDOMS' JURISPRUDENCE.
}

\section{A. Charter jurisprudence and legal doctrine with respect to the application of international human rights law domestically.}

In addition to being the primary legal means of enforcing human rights against state institutions since 1982, the Canadian Charter, in the words of Canadian International legal scholar Anne Bayefsky, has also led to "an exponential growth", of cases that employ international human rights norms in the Canadian legal context. ${ }^{23}$ Given the history of the document, it is hardly surprising that this would be so. ${ }^{24}$.Consequently, when designing the Charter, politicians and constitutional law experts looked to the international legal framework to draw inspiration in drafting a new bill of rights for Canada. "The legislative history of the Charter indicates that: 1) that international human rights were an important factor in the 15-year effort to constitutionalize a bill of rights and 2) many Charter provisions are specifically indebted in both language and intent, to specific international law provisions." ${ }^{25}$ For example, the tone of section 15's equality provisions clearly echoes article 26 of the International Convenant Civil and Political Rights [ICCPR]. ${ }^{26}$

Indeed, many social rights advocates and scholars assumed that the 1982 Charter implicitly recognized a range of basic second generation or socio-economic rights, including the right to adequate housing. "When the Charter was adopted in 1982, equality rights experts and advocacy groups considered the adequacy and accessibility of publicly funded programs, such as social assistance,

Tanudjaja, Appeal, supra note 18 at para 88.

23 Anne Bayefsky, International Human Rights Law: Use in Canadian Charter of Rights and Freedoms Litigation (Toronto: Butterworths, 1992) at 73.

24 See Bayefsky "the failure to include such express admissions or international guidelines can't deny the facts of the Charter's origins, and hence the inescapable relevance of international human rights norms in its interpretation." Ibid.

25 Ibid at 49.

26 Article 26 of the ICCPR reads "All persons are equal before the law and are entitled without any discrimination to the equal protection of the law. In this respect the law shall prohibit any discrimination and guarantee to all persons equal and effective protection against discrimination on any ground such as race, colour, sex, language, religion, or political or other opinion, national or social origin, property, birth or other status." International Covenant on Civil and Political Rights, 19 December 1966, 999 UNTS 171, art 26 [ICCPR]. 
universal healthcare, education and unemployment insurance, as implicit in these broadly framed Charter rights." 27

Given these parallels, it should come as no surprise that, from the beginning, Charter cases often cited the international legal framework with regard to the exercise of human rights in Canada, with particular importance placed on a range of Canada's international legal obligations stemming from treaties it had signed. No case epitomizes this early reliance on international legal norms better than $R$. $v$. Oakes. $^{28}$ This seminal criminal law case involving a reversal of the traditional burden of proof, demonstrates the extent to which Canadian jurists looked to the international level for guidance in deciding cases. Justice Dickson, in his much celebrated judgment, referenced the international legal situation with regard to the presumption of innocence, citing its general application ${ }^{29}$ as additional evidence of its value in human rights terms. Strangely enough, when you consider the large number of cases that might be more relevant to the issues raised by the application under review, this was the only example given by Lederer J. of the impact that international law has had on the application of Charter rights. He stated, "There is precedent for this. In R. v. Oakes, ${ }^{22}$ the Supreme Court of Canada considered the reference to the presumption of innocence in major international human rights documents as evidence of its 'widespread acceptance", 30

However, the impact of international human rights norms can be found in a broad spectrum of Canadian law involving everything from labour to administrative law. The former was the subject of the case Reference re Public Service Employee Relations Act (Alta.), the crux of which concerned labour relations law and the legality of an industrial action under the Charter. Justice Dickson, speaking for the minority, indicated "I believe that the Charter should generally be presumed to provide protection at least as great as that afforded by similar provisions in international human rights documents which Canada has ratified." "31 This doctrine was later upheld and expanded in Slaight Communications Inc. v. Davidson, another Charter case, in which the applicant invoked their freedom of expression rights, under s.2 (b). ${ }^{32}$ The case was decided on the basis of a s.1 exercise, but it is also noteworthy for having referenced the ICESCR in the context of the right to work and protecting vulnerable workers under the

27 Martha Jackman and Bruce Porter, "Socio-Economic Rights under the Charter" in Malcolm Langford, ed, Social Rights Jurisprudence: Emerging Trends in International and Comparative Law (Cambridge: Cambridge University Press, 2008) 209 at 209.

28 R. v Oakes, 1986 SCC 103 at para 31, [1986] 1 SCR 103, 1986 CanLII 46.

29 Ibid at 1

30 Tanudjaja, supra note 1 at para 150.

31 Reference re Public Service Employee Relations Act (Alta), [1987] 1 SCR 313 at para 59, [1987] SCJ no 10 (QL) [Public Service Employees].

32 For more recent case law on the presumption of conformity with international legal instruments binding Canada, see Divito v Canada (Public Safety and Emergency Preparedness), 2013 SCC 47, [2013] 3 SCR 157; Health Services and Support - Facilities Subsector Bargaining Association v British Columbia, 2007 SCC 27, [2007] 2 SCR 391, and in particular, the Federal Court application brought by Canadian Doctors for Refugee Care, et al., in which Mactavish J. found that the Supreme Court jurisprudence's "repeated use of the phrase 'at least as great' signals that Canadian Charter protections may, in some cases, actually exceed (emphasis added) those provided by international law." Canadian Doctors for Refugee Care v Canada (Attorney General), 2015 FCA 34 at para 445. 
Charter $^{33}$, as well as reaffirming the interpretive presumption established in Public Service Employees Relations Act. $^{34}$

Canadian administrative law's relationship with international human rights law is most obviously exemplified by the landmark decision of Justice Claire L'Heureux Dubé in Baker v. Canada (Minister of Citizenship and Immigration). In that instance, Justice L'Heureux Dubé was able to resolve a Charter claim partly by recourse to the international human rights norms enshrined in the International Convention of the Rights of the Child. Indeed, ministerial discretion was subject to such international law considerations, even though the document in question had not been incorporated in Canada's domestic legal framework, at the time. ${ }^{35}$

\section{B. The Legal Value of Evidence with Respect to International Human Rights Norms Presented by the Amnesty Factum and Others.}

Many Canadian jurists have argued for the inclusion of guidelines based on international human rights norms in the domestic judicial context. This is even more true of those enshrined in the ICESCR, which has not only been signed and ratified by the Canadian government but various representatives of the Canadian government have noted to the UN Human Rights Commission and the Committee on Economic, Social and Cultural Rights, that it is a major legal aide in Canadian human right's jurisprudence. "Canada has repeatedly affirmed that its social and economic rights obligations under the ICESCR are enforced specifically through the Charter." 36 Though many human right scholars will no doubt take issue with this as a misrepresentation of the actual jurisprudence, the Canadian government's portrayal internationally of its policies should be taken at its word, as a genuine statement, with respect to its commitment to see the Charter employed as a means of nurturing and promoting those international human rights norms entrenched in the ICECSR, including the right to adequate housing at the domestic level.

Others have joined the growing number of academics and activists in the housing rights field that are calling upon Courts and Judges to apply the ICESCR in their rulings. Lucie Lamarche has stressed that "le droit international devrait, s'inspirer les tribunaux canadiens à employer et à élaborer des contenus spécifiques pour des droits internes qui sont souvent trop flous." ${ }^{37}$ Martha Jackman has said that the few Charter cases that brought up the question of social rights have generally failed:

To recognize the basic social rights such as the right to food, shelter, health care, education and adequate housing, which are contained in most modern constitutions and which are well established in international human rights law...is all the more surprising

33 Slaight Communications Inc v Davidson, [1989] 1 SCR 1038 at 22, [1989] SCJ no 45 (QL).

34 Public Service Employees, supra note 31 at 8.

35 See para 69-71 in Baker $v$ Canada (Minister of Citizenship and Immigration), [1999] 2 SCR 817, [1999] SCJ no 39 (QL).

36 Gwen Brodsky, "The Subversion of Human Rights by Government in Canada" in Margot Young et al, eds, Poverty: Rights, Social Citizenship, \& Legal Activism (Vancouver: University of British Columbia Press, 2007) at 365.

37 Lucie Lamarche, "Le debat sur les droits sociaux au Canada respecte-ti-il la juridicite de ces droits? in Joel Bakan \& David Schneiderman, eds, Social Justice and the Constitution: Perspectives on a Social Union for Canada (Ottawa: Carleton University Press, 1992) at 37. 
given Canadian ratification in 1978 of the ICESCR and the country's long welfare tradition. ${ }^{38}$

Bruce Porter has similarly argued for the use of ICESCR in Canadian human rights jurisprudence on the grounds that "Referencing the Charter interpretation to social and economic rights and other substantive obligations under international human rights law will assist the courts in identifying and protecting the values fundamental to a free and democratic society. ${ }^{\prime 39}$ These opinions represent a small sample of the vast number of jurists and other experts on human rights law in Canada who advocate on behalf of social rights and emphasize the necessity of interpreting the Charter in the light of Canada's international legal obligations under the second U.N. Covenant.

\section{OVERVIEW OF PAST CHARTER JURISPRUDENCE INVOLVING INTERNATIONAL HUMAN RIGHTS NORMS AND SECTION $7 \& 15$}

\section{A. Contrasting the Decision in Tanudjaja with Past Decisions of the Supreme Court and lower Courts Involving the Application of International Human Rights Norms to Section 7's Legal Rights.}

Although Canadian jurisprudence has never before dealt directly with the matter of the right to adequate housing in Canadian law, the case law of the Supreme Court does feature many cases involving Section 7's right to life, liberty and personal security. Of these cases, quite a few make reference to international human rights norms in drawing their conclusions about the proper application of s.7 in Canadian law.

The earliest among these is Irwin Toy which expressly endorses the ICESCR in its reasoning and contains an opinion by Chief Justice Dickson which lays down the criteria for the minimal impairment doctrine with respect to freedom of expression under s.2 (b) of the Charter, still in use today. ${ }^{40}$ However, it is the obiter dictum delivered by Justice Antonio Lamer, on the justiciability of socioeconomic rights in Canada that is more relevant for our purposes here. The Supreme Court asked whether rights that contained an economic element could be read into s.7's security of the person clause. The Court did not provide an answer but did refer to lower court decisions that had "found that the rubric of 'economic rights' embraces a broad spectrum of interests... included in various international covenants, as rights to social security, equal pay for equal work, adequate food, clothing shelter, to traditional property - contract rights." ${ }^{\prime 1}$ This passage, although rather slight, has been interpreted by many jurists as leaving the door open to a possible positive dimension to the rights enumerated in s.7. However, Porter cautions us that "if the potential of Section 7 to protect rights such as the right to food, clothing and housing, referred to in Irwin Toy is to be realized...the positive components of these rights must clearly achieve greater recognition." ${ }^{\prime 2}$ At any rate, the question of whether social and economic

Ibid at 26.

39 Bruce Porter, "Judging Poverty: Using International Human Rights Law to Refine the Scope of Charter Rights" (2000) $15 \mathrm{~J}$ L \& Soc Pol'y 117 at 26.

40 Irwin Toy Ltd. v. Quebec (Attorney General), [1989] 1 SCR 927, [1989] SCJ no 35 (QL), 1989 CanLII at 87.

41 Ibid at 79 .

42 Porter, supra note 39 at 34. 
rights can be read into s.7 of the Charter remains an open one, and has yet to be put to bed by subsequent rulings of the Supreme Court, including the landmark Gosselin case in 2003 that considered a Charter challenge on the grounds of an inadequate level of social assistance benefits given to the applicant who had not enrolled in a workfare program. ${ }^{43}$ Hence, it is simply not a settled point of law, as Lederer suggested in his ruling.

In Ewanchuck a case involving sexual assault that hinged on the issue of whether the victim had given her consent or not, Justice Claire L'Heureux Dubé wrote an opinion in which she referenced the U.N. Convention on the Elimination of All Forms of Discrimination Against Women ${ }^{44}$ an international treaty signed and ratified by Canada, as proof of the government's commitment to ending violence towards women. Furthermore, she indicated that the

Charter is the primary vehicle through which international human rights achieve domestic effect....In particular s.15 (equality provisions) and s.7 (which guarantees the right to life, security and liberty of the person) embody the notion of respect of human dignity and integrity. ${ }^{45}$

Justice Lederer's analysis also looked at the British Columbia Appeals Court's precedent in Victoria v. Adams for an illumination of s.7's possible relationship with the right to adequate housing in Canada. The facts of the case concerned the homeless community in the city of Victoria challenging a city bylaw that prohibited the building of temporary shelters in public parks where the litigants lived. They not only maintained that this violated their s.7 rights to life, liberty and the security of person, but also that the latter must be viewed through the lens of international human rights law. As Justice Ross put it, "they seek to have reference to the international covenants as an aid in the interpretation of the meaning and scope of rights under the Charter." ${ }^{46}$ Justice Ross also mentioned specifically the Universal Declaration of Human Rights and the ICESCR's Article $11,{ }^{47}$ as being important considerations when courts in Canada look at socio-economic rights under s.7. In her conclusion, she stated clearly that "while the various international instruments do not form part of the domestic law of Canada they should inform the interpretation of the Charter and in this case, the scope and content of s.7." ${ }^{\prime 8}$ This aspect, among others, of her decision, was subsequently upheld by the British Columbia Court of Appeal, in its review of the case. ${ }^{49}$

43 See the majority opinion of Justice Beverly McLachlin, who wrote "The question therefore is not whether s.7 has ever been, or ever will be, recognized as creating positive rights (emphasis added). Rather, the question is whether the present circumstances warrant a novel application of s.7 as the basis for a positive state obligation to guarantee adequate living standards. I conclude that they do not." Gosselin v Quebec (Attorney General), [2002] SCC 84 at para 82, [2002] 4 SCR 429.

44 Convention on the Elimination of All Forms of Discrimination against Women, 3 September 1981, UN Doc A/34/46, online: University of Minnesota $<$ http://www1.umn.edu/humanrts/instree/e1 cedaw.htm>.

$45 \quad$ R. $v$ Ewanchuck, 19991 SCR 330, 1999 CanLII 711 at para 73.

46 Victoria (City) v Adams, 2009 BCSC 1363 at para 95, [2009] BCJ no 1972 (QL).

$47 \quad$ Ibid at para 87.

48 Ibid at para 100.

49 Justice Groberman states the following "the use of international instruments to aid in the interpretation of the meaning and scope of rights under the Charter, and in particular the rights under s.7 and the principles of fundamental justice, is well established in Canadian jurisprudence." Victoria (City) v Adams, [2009] BCCA 563 at para 35, 313 DLR (4th) 29. 
Curiously, Justice Lederer chose to ignore this aspect of the case. Instead, to the limited extent that he found it relevant, he focused on the negative dimension of the Charter claim, which does not request a state intervention to create temporary shelter, but rather aimed to strike down a by-law that denied the homeless claimants the ability to protect themselves from the elements by the building of such structures, thus impairing their right to personal security, under s.7.50 Moreover, somewhat unnecessarily, as it was never at issue in Tanudjaja, he goes on to criticize the British Columbia Court of Appeal for recognizing a right to build shelters, which, if true, would amount to a "property right." ${ }_{1}$ A finding that he deemed both baseless in Canadian law and one that contradicted the Supreme Court of British Columbia's ruling in Johnston v. British Columbia. ${ }^{52}$

This element of the Tanudjaja judgment is problematic, in at least two ways. Firstly, it overlooks what is arguably a key component of the applicant's Charter argument in Victoria with respect to the impact of international human rights law on Canadian human rights in general and on s.7 rights in particular. Secondly, it is also questionable, in a more technical legal sense. By this, I mean it is well established in Canadian law that as a matter of common law, according to the hierarchical nature of the court system, lower courts are bound by the precedents set by courts that are constitutionally above them..$^{53}$ Given the federal nature of Canada's judiciary, it is not uncommon for court decisions to go beyond their jurisdiction of origin and be applied by judges throughout Canada. ${ }^{54}$ The British Columbia Court of Appeal is the highest appellate court in that province, and though it may be in another jurisdiction, and thus its precedents are not strictly speaking binding, it remains above the Ontario Superior Court, in the legal hierarchy. Therefore, Justice Lederer was not sufficiently honouring this fundamental common law principle when he neglected to at least acknowledge the persuasive precedent set with respect to the application of international human rights norms concerning s.7 in Adams, in his Tanudjaja decision. Yet, he had no trouble citing the precedent in the related case of Johnston, another British Columbian case, as proof that "Section 7 of the Charter does not provide a positive right to affordable, adequate, accessible housing and places no positive obligation on the state to provide it." 55

Section 7's fundamental justice clause, has also been the subject of scrutiny from an international human rights perspective in a number of significant cases. In the B.C. Motor Vehicle Act Reference, Justice Lamer's opinion included a reference to the principles found in "international conventions of

$50 \quad$ Tanudjaja, supra note 1 at para 79.

$51 \quad$ Ibid at para 80.

$52 \quad R v$ Johnston, 2006 BCSC 1592 at para 11, [2006] BCJ no 2817 (QL).

53 See Elaine Mak for a concise description of stare decisis "In the common law tradition, this guides the interpretation of the law by the highest courts. The highest courts in principle follow their own prior decisions when judging later cases (horizontal precedent). Furthermore, the trial courts within a specific jurisdiction are bound by the judgements on questions of law issued by the higher courts in that system (vertical precedent)." Elaine Mak, Judicial Decision-Making in a Globalised World: A Comparative Analysis of the Changing Practices of Western Highest Courts (Oxford: Hart Publishing, 2013) at 32.

54 See for example Barbeau v British Columbia, 2003 BCCA 406, 228 DLR (4th) 416 where the Court cited the ruling of the Ontario Court of Appeal with regard to that court's finding that the common law definition of marriage as being between a man and women, contravened s.15 and was not saved by s.1. Halpern v Canada (AG), 2002 CanLII 42749 (SC), 60 OR (3d) 321.

55 Tanudjaja, supra note 1 at para 81. 
human rights" in his analysis of the meaning of rights found throughout s. 8 to s.14 in relation to defining the scope of s.7's guarantee of life, liberty and security of the person. ${ }^{56}$

In the 2002 Suresh case, a s.7 claim that the applicant's deportation order was inconsistent with the principle of fundamental justice and was, therefore, a violation of his Charter rights was resolved in part by recourse to the international legal framework surrounding torture. ${ }^{57}$ Specifically, the case revolved around a clause in the Immigration Act (s.53(1)(b)), which allowed the deportation of someone who posed a danger to national security to a country where his rights under the Charter would be threatened ${ }^{58}$ It transpired that the Court found in the applicant's favour, granting him another hearing, partly on the grounds that the Minister's exercise of authority and the order of a refoulement was in breach of international human rights custom, in light of the considerable risk of torture, in this particular case. The majority held:

Both domestic and international jurisprudence suggest that torture is so abhorrent that it will almost always be disproportionate to interests on the other side of the balance, even security interests. This suggests that, barring extraordinary circumstances, deportation to torture will generally violate the principle of fundamental justice protected by s.7 of the Charter. ${ }^{59}$

The question of the legal meaning of, among other things, the principle of fundamental justice in the context of a Charter claim was again raised in the 2004 case of Canadian Foundation for Children, Youth and the Law, in relation to an impugned section of the Criminal Code, which permitted parents to use corporal punishment in order to discipline their children. ${ }^{60}$ This time no less than five major international legal documents were cited in both the majority and dissenting opinions of the four judicial authors. Chief Justice McLachlin referenced the Convention on the Rights of the Child as well as the Convention on the Elimination of All Forms of Discrimination against Women in attempting to define the term "best interests of the child." ${ }^{61}$ The European Convention on Human Rights was also cited for its prohibition of "cruel and unusual treatment." ${ }^{2}$ As well, the three dissenting justices were equally interested in what international human rights norms had to say about the rights of children, in coming to their contradictory conclusions. Justice Arbour wrote that The International Convention on Civil and Political Rights and the UN Convention on the Rights of the Child were important sources of legal information when trying to understand the degree of protection afforded children under s.7. ${ }^{63}$ Justice Deschamps, also made reference to these "international legal authorities" in her opinion relating to the correct application of the Charter's equality rights to the law in question. ${ }^{64}$

\footnotetext{
Reference Re section 94(2) of the Motor Vehicles Act, [1985] 2 SCR 486 at 503, 1985 CanLII 81.

Suresh, supra note 2 at 1.

58 See section 115 of the current act on the principle of non-refoulement, Immigration and Refugee Protection Act, RSC 2001, c 27 at s 115.

59 Suresh, supra note 2 at para 76.

60 Canadian Foundation for Children, Youth and the Law v Canada (Attorney General), 2004 SCC 4 [2004] 1 SCR 76

61 Ibid at para 10.

62 Ibid at para 34.

63 Ibid at para 186.

64 Ibid at para 225.
} 
Finally, the issue of international human rights arose in the now infamous case of Canadian Omar Khadr, who was only fifteen years of age when he was taken from a battlefield in Afghanistan to an American military prison in Guantanamo Bay, Cuba, where he was interrogated by both American and Canadian officials for his role in the death of a U.S. army medic. Understandably, the case was highly controversial in Canada and generated a great deal of publicity both in the country and around the world. $^{65}$

The Canadian government had mostly washed its hands of Mr. Khadr's appeal against his detainment and trial. However, it had played a part in his interrogation, covertly sending agents from Canada's security agency [CSIS] to gather evidence for intelligence and law enforcement purposes. ${ }^{66}$

It was this action that was under scrutiny from the Supreme Court bench. The court unanimously ruled that the appeal should be rejected and the lower court ruling upheld. It described the case as raising "the relationship between Canada's domestic and international human rights commitments." ${ }^{67}$ The former was engaged by Mr. Khadr's right to liberty under s.7 which had been infringed, and found that his request that the government be required to turn over all documents relevant to the charges against him in the possession of the state, including material yielded through interrogations carried out by Canadian officials, should, therefore, be granted. ${ }^{68}$ The case also engaged international human rights norms (specifically humanitarian law on the treatment of prisoners of war) under the Geneva Conventions $^{69}$, in particular that document's guarantee of habeas corpus, which was deemed to have been breached by the Military Commission in Guantanamo Bay responsible for the trial of Mr. Khadr, among others. The end result was, in the Court's judgment, a miscarriage of justice.

[A]n individual's s. 7's right to liberty is engaged by Canada's participation in a foreign process that is contrary to Canada's international human rights obligations, s. 7 of the Charter imposes a duty on Canada to provide disclosure to the individual. Thus, s. 7 imposes a duty on Canada to provide disclosure of materials in its possession arising from its participation in the foreign process that is contrary to international law and jeopardizes the liberty of a Canadian citizen. ${ }^{70}$

As James Yap and Patrick Monahan noted in their review of the Khadr case: "Another effect of the Khadr decision is that it also firmly entrenches the role of international human rights law in Charter litigation." 71

\footnotetext{
65 “Omar Khadr's Legal Odyssey: From Guantanamo Bay to Alberta”, The Canadian Press (9 March 2015), online: CBC News Politics < http:/www.cbc.ca/news/politics/omar-khadr-s-legal-odyssey-from-guantanamo-bay-to-alberta$1.2987034>$.

66 Michelle Shepard, “Canada violated Khadr's Rights: Supreme Court Rules”, The Toronto Star (23 March 2008) online: Toronto Star < http://www.thestar.com/news/canada/2008/05/23/canada_violated_khadrs_rights_supreme_court_rules.html>.

67 Canada (Justice) $v$ Khadr, 2008 SCC 28 at para 1, 2 SCR 125 [Khadr].

68 Ibid.

69 See in particular articles $(100,102 \& 104)$ relating to judicial proceedings against prisoners of war in the Geneva Convention Relative to the Treatment of Prisoners of War, 21 October 1950, 75 UNTS 135, Can TS 1965 No 20.

70 Khadr, supra note 67 at para 31.

71 Patrick Monahan \& James Yap, Constitutional Cases in 2008: An Overview (2009) 47 SCLR (2d) at 13.
} 
It should be obvious that the above bears no resemblance factually to the Tanudjaja appeal. However, despite the diverse facts and arguments presented in the aforementioned s.7 Charter cases, all serve to demonstrate one significant legal point. That is to say, each case, though they may have applied it differently, makes use of internationally recognized principles of human rights as a guide to the way in which Charter claims ought to be approached in the Canadian human rights and constitutional law context, with particular reverence for those obligations in international law that are strictly binding on Canada.

\section{B. Contrasting the Decision in Tanudjaja with Past Decisions of the Supreme Court Involving the Application of international Human Rights Norms and Section 15 Equality Rights.}

From its inception, the Charter's right to equality was viewed by Canadian judges as being largely derived from universally accepted legal norms with respect to the right to equal treatment under the law, specifically the ICCPR's article $12 .{ }^{72}$ Indeed, much of the Supreme Court's jurisprudence in this area is regarded internationally to be among the leading precedents in establishing substantive equality rights that contain positive aspects which require governments not simply to create formal equality under the law, but also to empower disadvantaged groups in society. As Jackman and Porter have stated:

In its early section 15 Charter jurisprudence, the Supreme Court of Canada played a leading role, internationally, in affirming and developing a notion of substantive equality that includes important dimensions of socio-economic rights and places positive obligations on governments to remedy disadvantages. ${ }^{73}$

Under the obligation to respect, established by the ICESCR, parties to the treaty must ensure that any measures taken by state actors ensure that private entities or individuals do not take any action that would harm a person's access to relevant rights. ${ }^{74}$ In the case of Eldridge, the Supreme Court was faced with just such a thorny issue. It found that the hospital in question, although more or less a private entity, was providing a public service in the form of healthcare, and was, thus, subject to the equality provisions of the Charter. ${ }^{75}$ As Jackman and Porter say in their contribution to Chapter 11 of Social Rights Jurisprudence, "[t] he standard of reasonableness applied in the Eldridge case is...more consistent with the requirement under article 2 of the ICESCR that a government take 'steps...to the maximum available resources' to realise socio-economic rights." 76

In the judgment delivered by Lederer J., Eldridge is cited and distinguished from Ms. Tanudjaja's claim. The judge recognizes that the Court had found a positive dimension to $\mathrm{s} .15$ (1) insofar as it provides for an interpreter for the hearing impaired in hospitals where such a service is required. He then dismisses the relevance to the claim before the court on the grounds that "the action it compelled was not directed to the provision of programs to deal with a societal concern, but to ensure that an existing

ICCPR, supra note 24.

Jackman \& Porter, supra note 27 at 25.

74 See Committee on Economic, Social and Cultural Rights, General Comment No 12, Right to adequate food (Twentieth Sess, 1999), UN Doc E/C.12/1999/5(1999) at para 15.

75 Eldridge $v$ British Columbia (Attorney General), [1997] 3 SCR 624, [1997] SCJ no 86 (QL).

76 Jackman \& Porter, supra note 27 at 219-220. 
benefit the state was already delivering was provided in a manner that did not discriminate." ${ }^{\prime 7}$ Therefore, he differentiated what was being sought by the claimant in Tanudjaja from the fact that in Eldridge the government program in question, healthcare, already exists and furthermore, guarantees of equality of benefits are in accordance with the Charter. While it may be correct, that Eldridge has not created a general positive obligation binding the state to provide services to redress inequities in Canadian society, it is surely a misreading of the case to say, as Justice Lederer does, that the Court did not require positive measures to be taken by the state on the grounds of a breach of s.15(1) owing to its discriminatory behaviour. On the contrary, it should be noted that the Supreme Court found "[t]he principle that discrimination can accrue from a failure to take positive steps to ensure that disadvantaged groups benefit equally from services offered to the general public is widely accepted in the human rights field." 78

In another major case involving equality rights, the Supreme Court ruled in favour of the claimant on the grounds that he had been unfairly discriminated against by the Law Society of British Columbia which had refused him membership to the bar in that province on the grounds that he was not a citizen of Canada. In a dissenting opinion penned by McIntyre J., which examined, among other things, the relationship between s.15 and s. 1 of the Charter, the Justice referred to the European Convention on Human Rights (specifically article 14 of the ECHR) in distinguishing the way it was applied from the way that s. 15 is in the Canadian context generally, and specifically in the case before him. ${ }^{79}$

Despite these cases providing evidence to the contrary, Justice Lederer concluded that it was unnecessary to do even a comparative analysis between the international legal instruments dealing with the right to adequate housing and the pertinent sections of the Canadian Charter. Rather, he dismissed their relevance to the case, saying "whatever international treaties may say about housing as a right is not of much help. ${ }^{, 80} \mathrm{He}$ then reiterated his earlier argument by referring to the Charter equality rights provisions contained in s.15. "Have the applicants been denied a benefit given to others as a result of actions by the state or has such action imposed a burden on the applicants that others have not been subjected to?"

\section{CONCLUSION}

The outcome in Tanudjaja is clearly unsatisfactory for the Canadian human rights scholar interested in housing rights and its exercise under Canada's constitution. As I have discussed in this paper, it seems to fly in the face of so much of the Charter jurisprudence, doctrine and expert legal opinion of the past thirty years. Furthermore, it is inconsistent with the traditional interpretation of Canadian courts that it is necessary and appropriate to refer to the relevant international legal documents, opinion and jurisprudence, for guidance in their application, particularly with respect to constitutionally guaranteed

Tanudjaja, supra note 1 at para 73.

Eldridge, supra note 75 at para 78.

Justice McIntyre indicated that "article 14 of the European Convention on Human Rights... which secures the rights guaranteed therein without discrimination, lacks an s. 1 or its equivalent and has also developed a limit within the concept itself." Andrews v Law Society of British Columbia, [1989] 1 SCR 143 at 37, [1989] SCJ no 6 (QL).

80 Tanudjaja, supra note 1 at para 150.

81 Ibid. 
human rights. Justice Lederer seems to have encouraged the applicants and their intervenors by acknowledging in his opinion that the latter should be allowed to make submissions to the case that international human rights norms (citing as an example the ICESCR, among others) are relevant to the interpretation of s. 7 and s. 15 in the context of Canadian human rights. However, these submissions appear to have been discarded in his final analysis and evidently were not a consideration in his rejection of the application. Justice Lederer's reasoning for this was, as he simply stated in paragraph 150, that "[t]he fundamental questions respect the tests set for a right to be recognized as protected by the Charter." ${ }^{" 22}$ Accordingly, the question under review, is a matter for domestic law and no reference to international law is necessary. Yet the Charter rights in question have to some degree been derived from international legal principles found in certain human rights documents and have also been the subject of a great deal of comparative analysis with international human rights instruments, jurisprudence and doctrine in past Charter claims involving the same sections.

This dualist perspective, under which there is a clear separation of international and domestic legal systems is of course, not uncommon among Canadian judges and a clue to the theoretical framework to which Justice Lederer appears to subscribe, can be found in the sources listed in the application's legal bibliography. Among the most important of which, appears to be Lorne Sossin's work, Boundaries of Judicial Review, a study of the limits imposed on justiciability by Canadian law, specifically with respect to the judiciary. Though Sossin remains open to the use of international legal principles by Canadian judges, he qualifies this by saying "it would appear that the questions of international law are justified in Canadian courts so long as they are considered in the context of a domestic legal issue. ${ }^{" 83}$ Strict though this reading of Canadian jurisprudence may be, it does not exclude the possibility of applying international human rights norms to the case at hand. After all, this challenge surely qualifies as one that involves interrelated international and domestic legal dimensions. Thus Sossin's point about justiciability, is not, and should not be used as a defense of Justice Lederer's approach in Tanudjaja.

But the omission of any substantive analysis of international legal norms in the domestic context is not the only aspect of the judgment that is questionable. Lederer J. also neglects the government of Canada's repeated declarations at the United Nations with respect to their compliance with international human rights. ${ }^{84}$ In their submissions to the Committee for the ICESCR, for instance, the Federal government has stated that s.7 must be interpreted in the light of Canada's obligations under the Covenant to ensure that the basic needs of its citizens are being met. ${ }^{85}$ Moreover, as has been pointed out

82 Ibid

83 Lorne Sossin, The Boundaries of Judicial Review: the Law of Justiciability in Canada, 2d ed (Toronto: Carswell, 1999) at 197.

84 It must be said many human rights scholars have called into question the sincerity of these declarations. See for example Gwen Brodsky who writes that privately that the federal government opposes such a reading of the Charter but, for whatever reason "the Canadian government will not say publicly that they do not believe that Canadians should enjoy these human rights or that they ever intended social \& economic rights commitments to be enforced domestically" Brodsky, supra note 36 at 365.

85 In the context of a 1993 report submitted to the Committee, the federal government described its understanding of the relationship between s.7 and its Covenant obligations the following way: "While the guarantee of security of the person under section 7 of the Charter might not lead to a right to a certain type of social assistance, it ensured that persons were not deprived of the basic necessities of life." Summary Record of the 5th Meeting, ESC, 8th Sess, 5th Mtg, UN Doc E/C.12/1993/SR.5 (25 May 1993) at para 21. 
by many Canadian legal scholars with respect to the implementation of housing rights or other socioeconomic rights in Canada "[a] broad and purposive reading' of section 7, as recommended by the CESCR, would complement the substantive approach to equality already affirmed by the Supreme Court, capturing the interdependence of equality, dignity and security issues and of international and domestic human rights. ${ }^{966}$

Indeed, the advice to member states of the Committee on implementation of the second Covenant, with respect to equality rights generally, might also serve as a good starting point for judges faced with cases involving social and economic human rights like the one in Tanudjaja. That international body has strongly encouraged a broader reading of s. 15 type equality provisions, to include economic social and cultural rights ${ }^{87}$

We can only hope that the decision of the Supreme Court of Canada not to hear Tanudjaja is not the end of the debate in Canada with respect to this significant, and sadly all too rare, example of a legal action that seeks to advance fundamental human rights of a socio-economic nature. And, furthermore, that in any future litigation of this type, the justices that preside over the hearing will give more careful consideration to the relevant international human rights norms contained in the ICESCR and other documents, and the way in which they bolster claims like those of Ms. Tanudjaja. As well as giving greater legal weight to the established law of Canada with respect to the application of such norms in the context of Charter cases involving both claims to $\mathrm{s.15}$ and s.7, much of which has been developed by the Supreme Court of Canada and continues to shape Canadian jurisprudence dealing with a wide variety of human rights issues domestically.

\footnotetext{
86 Porter, supra note 39 at 155.
}

87 General Comment No 9, The domestic application of the Covenant, Report of the Ninth Session, UNCESCR, 1998, UN Doc E/C.12/1998/24, online: The UN Refugee Agency < http://www.refworld.org/docid/47a7079d6.html>. 